\title{
Palaeoecology and palaeophytogeography of the Rhynie chert plants: evidence from integrated analysis of in situ and dispersed spores
}

\author{
Charles H. Wellman \\ Department of Animal and Plant Sciences, University of Sheffield, Alfred Denny Building, Western Bank, \\ SheffieldS10 2TN, UK (c.wellman@sheffield.ac.uk)
}

\begin{abstract}
The Rhynie cherts yield exceptionally preserved early land plants, and provide a unique insight into the nature of Lower Devonian vegetation. Hitherto they have been poorly age constrained, and the palaeoecology and palaeophytogeography of the flora are poorly understood. Well-preserved dispersed-spore assemblages have been recovered from a number of borehole cores through the stratigraphical sequence of the Rhynie outlier. They are all similar and belong with the polygonalis-emsiensis (PE) spore zone, indicating an Early Devonian age (Early (but not earliest) Pragian to earliest Emsian). Comparisons with PE sporezone assemblages from elsewhere suggest that the flora of the Rhynie drainage basin was slightly impoverished, with certain plant taxa that occurred at other locations not represented. This probably reflects differences between the flora of an inland intermontaine basin (Rhynie) and that of the lowland floodplains. In situ spores have been characterized for all seven Rhynie chert plants. Analysis of the distribution of these spore types in the Rhynie sequence, in addition to those of coeval deposits from elsewhere, enables interpretation of the palaeoecology and palaeophytogeography of the Rhynie chert plants. It is concluded that at least some of the plants were not highly specialized or adapted to the peculiar hot-springs environment in which they are preserved. Rather, they were components of a diverse and widespread flora, but were the only elements able to tolerate the inhospitable hot-springs environment (i.e. they were preadapted).
\end{abstract}

Keywords: Lower Devonian; Rhynie chert; early land plants; spores

\section{INTRODUCTION}

The Early Devonian Rhynie cherts contain a terrestrial ecosystem exceptionally preserved in its entirety (Powell et al. 2000; Rice et al. 2002), and provide a unique insight into early terrestrial ecosystems and their components. The biota is exceptionally preserved by silicification, in sinters deposited by hot-spring activity associated with a complex hydrothermal system (Trewin \& Rice 1992; Trewin 1994, 1996; Rice et al. 1995, 2002). The fossil plants preserve exceptional cellular detail (Kidston \& Lang 1917, $1920 a, b, 1921 a, b)$, including stages of the life cycle seldom fossilized, such as germinating spores (Lyon 1957; Remy \& Hass 1996) and gametophytes (Remy \& Remy 1980; Remy et al. 1993). Arguably, the reconstruction and interpretation of early land plants is overwhelmingly reliant on the extraordinary detail provided by the Rhynie plants. This is problematic, because the Rhynie plants clearly inhabited an extremely unusual environment, and it has been suggested that they were specialized and highly adapted (e.g. Scott 1920; Darrah 1960). Consequently, there is a danger that the Rhynie plants may not be typical Lower Devonian plants, and our interpretation of early land plants may be highly biased or even erroneous.

The aim of this report is twofold: first, to describe dispersed-spore assemblages from the stratigraphical sequence of the Rhynie outlier; and second, to characterize the in situ spores preserved in the Rhynie plants. The well-preserved dispersed-spore assemblages provide, for the first time, a reliable biostratigraphical age constraint for the Rhynie deposits. Additionally, comparisons with coeval dispersed-spore assemblages from different palaeogeographical areas and palaeoenvironments enable an evaluation of the diversity, palaeoecology and palaeophytogeographical distribution of the flora of the Rhynie drainage basin. Characterization of the in situ spores of the Rhynie chert plants enables their identification within dispersed-spore assemblages from the Rhynie sequence and in coeval assemblages from elsewhere. Integrating data from in situ and dispersed spores permits: (i) investigation of the contribution of the Rhynie plants to local dispersed-spore assemblages, and hence interpretation of the temporal and spatial distributions and ecology of these plants with respect to the local flora; and (ii) interpretation of the palaeophytogeography and palaeoecology of the Rhynie chert plants with respect to the regional flora.

\section{GEOLOGICAL SETTING}

The Rhynie cherts (Rhynie outlier, Aberdeenshire, Scotland, UK) are nowhere exposed, and were until recently known only through loose blocks that occur at the surface and through trenching. Consequently the geology of these deposits was poorly understood. Recently, however, a series of boreholes was sunk to investigate the deposits, including a deep borehole that penetrated $210 \mathrm{~m}$ of sedimentary sequence before encountering igneous basement (Rice et al. 2002). These boreholes have, for the first time, revealed the nature of the Rhynie stratigraphical sequence and in particular the relationships between the chert horizons and the fluviatile and lacustrine deposits above, interspersed with and below 


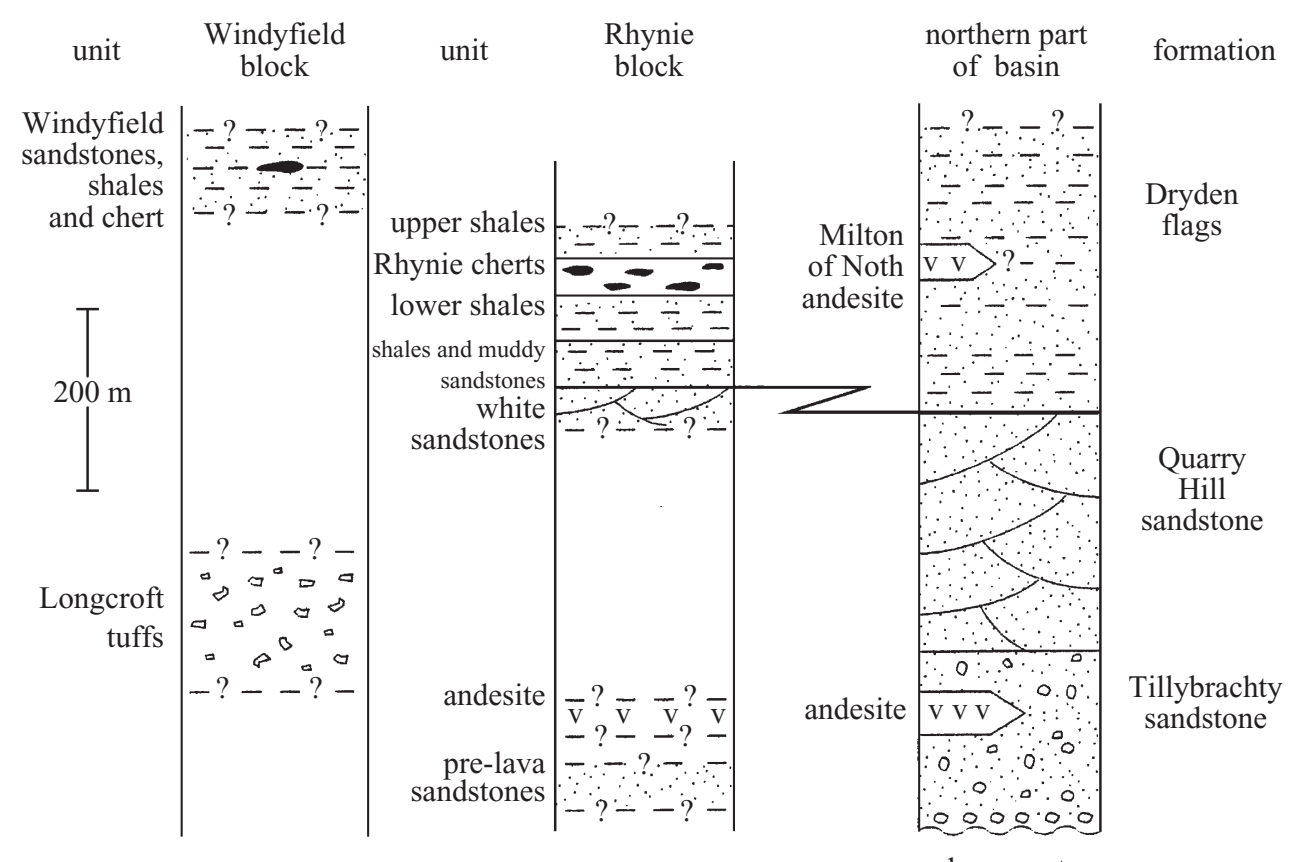

Figure 1. Proposed correlation of the stratigraphical successions developed in the Rhynie outlier (from Rice et al. 2002, with permission).

the cherts (Trewin \& Rice 1992; Trewin 1994, 1996; Rice et al. 1995, 2002). These new data have led to improved interpretation of the geology of the Rhynie outlier and, of particular relevance here, the palaeoenvironments represented by the deposits (Powell et al. 2000; Rice et al. 2002).

The strata are interpreted as having accumulated in a subsiding half-graben. The sequence comprises predominantly fine-grained sediments that accumulated as fluviatile and lacustrine deposits on an alluvial plain with local lakes. For a period of time the area was affected by hotspring activity. The cherts represent the surface expression of hot springs associated with a complex hydrothermal system. The flooding of small pools by silica-rich waters preserved an aquatic biota of cyanobacteria (Croft \& George 1959), algae (Edwards \& Lyon 1983) and arthropods. The terrestrial biota surrounding these pools was preserved by siliceous fluids, which migrated downwards from surface flooding and permeated upwards from the underlying hydrothermal vents. It consists of plants, fungi (Taylor \& Taylor 2000), lichens (Taylor et al. 1997) and arthropods. The plants are preserved in growth position, as litter lying on the substrate and as organic matter in rudimentary soils. Preservation was essentially instantaneous (Powell et al. 2000).

\section{MATERIAL AND METHODS}

\section{(a) Dispersed-spore assemblages}

Standard palynological techniques ( $\mathrm{HCl}-\mathrm{HF}-\mathrm{HCl}$ bulk acid maceration) were used to isolate the organic contents of 118 samples of fine-grained sediments. These were collected from a number of the boreholes that contain suitable sediments. The sampling regime essentially covered the entire bored sequence, including clastic sediments from above and below the chertbearing sequence and interspersed with the cherts within the chert-bearing sequence. Figure 1 illustrates the stratigraphical sequence of the Rhynie outlier, and table 1 summarizes the stratigraphical coverage of the palynological sampling regime. The recovered palynomorph assemblages are dominated by spores, but also contain plant cuticles (embryophyte and nematophyte), tubular structures (including fungal hyphae), rare algal remains and arthropod cuticles. The palynomorphs are extremely well preserved and of relatively low thermal maturity. Detailed examination of the dispersed spores using light and scanning electron microscopy enabled taxonomic characterization of the taxa present, and determination of their distribution and relative abundances throughout the sequence (table 2). To assess the nature of the flora of the Rhynie drainage basin, the dispersed-spore assemblages were biostratigraphically age constrained and compared with coeval assemblages that are palaeogeographically widespread and representative of a variety of different palaeoenvironments.

\section{(b) In situ spores}

A detailed study was undertaken on in situ spores contained within Rhynie chert plants that are exceptionally preserved in the chert horizons. All of the major collections of sectioned Rhynie chert were visited and relevant specimens examined in detail. These collections are housed in: the Hunterian Museum, Glasgow, UK; the Natural History Museum, London, UK; Westfalische Wilhelms-Universitat, Münster, Germany; University of Aberdeen, UK; and Cardiff University, UK. Specimens containing in situ spores are known for all seven of the plants described from the Rhynie chert. Rather intriguingly, considering the excellent preservation of less recalcitrant organs, the in situ spores are often poorly preserved. For most taxa, however, at least a few specimens contain well-preserved spores, although these usually occur only in patches among the sporangial contents.

Previous studies of in situ spores from the Rhynie plants (Bhutta 1973a,b; Allen 1980; Gensel 1980; Edwards \& Richardson 1996) have been hampered for the following reasons: (i) rather surprisingly, in situ spores preserved in the cherts are often corroded and poorly preserved, and it is difficult to distinguish 
Table 1. Distribution of palynological samples from the Rhynie chert boreholes.

(Stratigraphical terminology after Rice et al. (2002). RB, Rhynie block; WB, Windyfield block; A, total number of palynological samples; B, number of barren samples; C, number of poorly preserved samples; D, number of moderately preserved samples; E, number of well-preserved samples.)

\begin{tabular}{|c|c|c|c|c|c|c|c|}
\hline geological block & stratigraphical unit & borehole & A & $\mathrm{B}$ & $\mathrm{C}$ & $\mathrm{D}$ & $\mathrm{E}$ \\
\hline \multirow{8}{*}{$\begin{array}{l}\text { RB (chert-bearing } \\
\text { sequence) }\end{array}$} & upper shales unit & $97 / 3$ & 11 & 0 & 6 & 3 & 2 \\
\hline & upper shales unit & MRD BH5 & 8 & 0 & 0 & 0 & 8 \\
\hline & Rhynie cherts unit & $97 / 2(0-50.5 \mathrm{~m})$ & 28 & 0 & 6 & 3 & 19 \\
\hline & Rhynie cherts unit & $97 / 8$ & 5 & 1 & 1 & 2 & 1 \\
\hline & Rhynie cherts unit & $97 / 9$ & 11 & 2 & 3 & 1 & 5 \\
\hline & lower shales unit & $97 / 2(50.5-98.0 \mathrm{~m})$ & 14 & 1 & 5 & 2 & 6 \\
\hline & shales and muddy sandstones unit & $97 / 2(98.5-161.0 \mathrm{~m})$ & 12 & 4 & 6 & 2 & 0 \\
\hline & white sandstones unit & $97 / 2(161.0-210.0 \mathrm{~m})$ & 10 & 4 & 4 & 2 & 0 \\
\hline \multirow{2}{*}{$\begin{array}{l}\text { WB (chert-bearing } \\
\text { sequence) }\end{array}$} & white sandstones unit & $97 / 1$ & 8 & 4 & 0 & 1 & 3 \\
\hline & white sandstones unit & $97 / 7$ & 10 & 2 & 4 & 4 & 0 \\
\hline $\begin{array}{l}\text { WB (basin-margin fault } \\
\text { zone) }\end{array}$ & white sandstones unit & $97 / 6$ & 1 & 0 & 0 & 1 & 0 \\
\hline
\end{tabular}

between original features, pre-silicification degradation and preservational artefact; (ii) there are difficulties in relating compressed dispersed spores to three-dimensionally preserved in situ spores; (iii) it is difficult to identify spore maturation state, i.e. immature spores; and (iv) early workers (e.g. Bhutta 1973a,b) often had few thin sections in which spores were well preserved, and relied on supplementary data from film pulls, chert chips and spores chemically isolated from the cherts. These problems were largely surmounted during the present study because the author gleaned a deep understanding of the spore types and morphologies present through detailed investigation of the exceptionally, and more conventionally, preserved dispersed spores. This opportunity was unavailable to previous workers, who thus struggled to identify artefacts as outlined above. Additionally, owing to the proliferation of new specimens preserving in situ spores (i.e. the Aberdeen and Münster collections), the author was able to examine far more sectioned material than were previous workers. Analysis of in situ spores enabled characterization of the spores of the seven plant taxa identified in the Rhynie chert (see $₫ 5$ and table 3 ).

It was assumed that, if the dispersed spores produced by the Rhynie plants could be accurately identified in dispersed-spore assemblages, their relative abundance and palaeophytogeographical and palaeoenvironmental distributions could be established. This provides evidence for the abundance, palaeophytogeography and palaeoecology of the parent plants. It must be stressed, however, that accurate identification of these spores is dependent on how morphologically distinctive they are.

\section{DISPERSED-SPORE ASSEMBLAGES}

\section{(a) Description}

The spore assemblages are approximately similar throughout the sequence, containing the same taxa, although the relative abundances vary to a small degree. Approximately 40 spore taxa are present, although only 32 of these are common. Only a brief description of the spore assemblages follows as a detailed systematic monograph is in preparation. Table 2 presents spore occurrences and abundance counts for a limited number of samples representative of the different stratigraphical units.

The dispersed-spore assemblages are dominated by laevigate forms that are retusoid (Retusotriletes spp.) (figure
$2 e-g, o$ ), crassitate (Ambitisporites spp.) or, more rarely, patinate (Archaeozonotriletes spp.). Apiculate retusoid forms (Apiculiretusispora spp.) (figure $2 c, d$ ) are also abundant and are represented by at least five taxa. Some of these are clearly bilayered with an inner laevigate body and an outer apiculate layer that is often partially shed. Spores with proximal radial ribs are common (Emphanisporites spp.) including forms that are distally laevigate (E. rotatus) (figure $2 p$ ) and apiculate (E. decoratus and $E$. zavallatus) (figure $2 h-k, m, n)$. Other ornamented spores include foveolate forms (Brochotriletes spp.), reticulate forms (Dictyotriletes spp. including $D$. emsiensis and $D$. subgranifer) (figure 2b), rare apiculate crassitate forms (Aneurospora sp.) and rare examples of Verrucosisporites polygonalis (figure $2 a$ ) with prominent distal polygonal verrucae. Zonate spores also occur but infrequently (figure $2 l$.

\section{(b) Biostratigraphy}

Throughout most of the research history of the Rhynie cherts, age dating was insecure and based largely on tentative lithostratigraphical correlation and/or rather unsatisfactory estimations of the 'evolutionary complexity' of the plants. Recently a ${ }^{40} \mathrm{Ar} /{ }^{39} \mathrm{Ar}$ radiometric date of $396 \pm 12$ Myr was provided, indicating a Pragian (Early Devonian) age (Rice et al. 1995). Spore assemblages provide, for the first time, a reliable biostratigraphical age. They belong to the polygonalis-emsiensis Spore Assemblage Biozone (PE zone). The age range of this zone, based on correlation with the recently ratified Global Stratotype Sections of the Pragian and Emsian (Streel et al. 2000), is early (but not earliest) Pragian to earliest Emsian (Richardson \& McGregor 1986). This is congruent with age estimates recently provided by radiometric techniques. Designation to this zone is based on the presence of key taxa, including the nominal species for the zone, and the overall composition and morphological characteristics of the assemblage.

\section{(c) Palaeogeographical implications}

The Rhynie deposits are believed to have accumulated in an intermontaine basin, located in the Caledonian highlands within the Old Red Sandstone continent. Rivers 


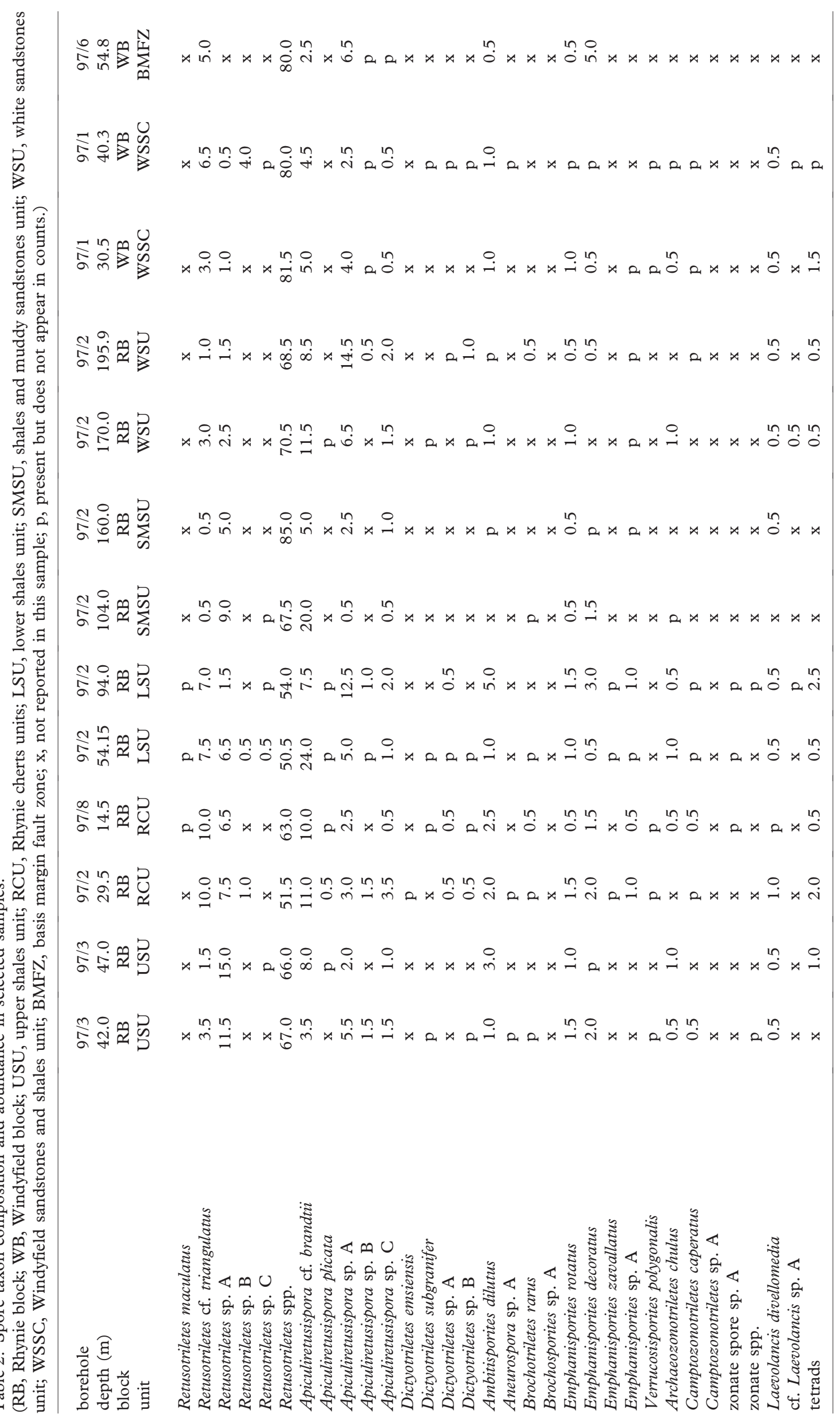


Table 3. Details of in situ spores.

\begin{tabular}{|c|c|c|}
\hline $\begin{array}{l}\text { plant and number of } \\
\text { specimens examined }\end{array}$ & $\begin{array}{l}\text { spore type and } \\
\text { abundance }{ }^{\mathrm{a}}\end{array}$ & observations \\
\hline $\begin{array}{l}\text { Rhynia gwynne- } \\
\text { vaughanii } \\
\quad \text { (11 specimens) }\end{array}$ & $\begin{array}{l}\text { Apiculiretusispora } \\
\text { plicata }(\text { mean }=0.5 \% \text {, } \\
\text { maximum }=7.5 \%)\end{array}$ & $\begin{array}{l}\text { In situ spores occur in various states of maturation, including mature single } \\
\text { spores and immature undissociated tetrads. Spores are distinctive with an } \\
\text { apiculate outer layer, which is often partially shed and is characteristic of } \\
\text { Apiculiretusispora. }\end{array}$ \\
\hline $\begin{array}{l}\text { Aglaophyton major } \\
\text { (20 specimens) }\end{array}$ & $\begin{array}{l}\text { Retusotriletes sp. A } \\
\quad(\text { mean }=4.7 \% \\
\text { maximum }=15 \%)\end{array}$ & $\begin{array}{l}\text { Spores retusoid and entirely laevigate, but with a distinctive thinning associated } \\
\text { with the trilete mark. }\end{array}$ \\
\hline Horneophyton & Emphanisporites & Spores with distinctive proximal radial ribs and distal apiculate ornament. \\
\hline $\begin{array}{l}\text { lignieri } \\
(47 \text { specimens })\end{array}$ & $\begin{array}{l}\text { decoratus } \\
(\text { mean }=1.3 \% \\
\text { maximum }=25 \%)\end{array}$ & $\begin{array}{l}\text { Material examined by Kidston \& Lang was immature (personal observation) and } \\
\text { hence they failed to recognize the characteristic features, clearly displayed in } \\
\text { specimens from Aberdeen, the Natural History Museum and Münster. }\end{array}$ \\
\hline $\begin{array}{l}\text { Asteroxylon mackiei } \\
\quad(9 \text { specimens) }\end{array}$ & $\begin{array}{l}\text { ?Retusotriletes } \mathrm{sp} \text {. } \\
\text { (always }>24 \% \text { ) }\end{array}$ & $\begin{array}{c}\text { Sporangia of this plant are rare, and those examined contained only poorly } \\
\text { preserved spores. These are difficult to characterize but are clearly of simple } \\
\text { morphology. }\end{array}$ \\
\hline $\begin{array}{l}\text { Nothia aphylla } \\
\qquad(21 \text { specimens) }\end{array}$ & $\begin{array}{l}\text { Retusotriletes sp. } \\
\text { (always }>24 \% \text { ) }\end{array}$ & $\begin{array}{c}\text { In situ spores are usually poorly preserved. Rare specimens contain occasional } \\
\text { well-preserved spores that have very simple morphology and are retusoid and } \\
\text { entirely laevigate. }\end{array}$ \\
\hline $\begin{array}{l}\text { Trichopherophyton } \\
\text { teuchansii } \\
\quad(2 \text { specimens })\end{array}$ & $\begin{array}{l}\text { Retusotriletes } \mathrm{cf} . \\
\text { triangulatus } \\
(\text { mean }=3.8 \%, \\
\text { maximum }=16 \%)\end{array}$ & $\begin{array}{l}\text { Spores retusoid and entirely laevigate. They have a characteristic darkening } \\
\text { associated with the trilete mark, but this is a common feature among Early } \\
\text { Devonian spores and has probably arisen as a result of homoplasy. }\end{array}$ \\
\hline $\begin{array}{r}\text { Ventarura lyonii } \\
\text { (1 specimen) }\end{array}$ & $\begin{array}{l}\text { ?Retusotriletes } \mathrm{cf} \text {. } \\
\text { triangulatus } \\
(\text { mean }=3.8 \%, \\
\text { maximum }=16 \%)\end{array}$ & $\begin{array}{l}\text { Sporangia with in situ spores are very rare, and spores are always very poorly } \\
\text { preserved. They are nondescript and similar to those of } T \text {. teuchansii. }\end{array}$ \\
\hline
\end{tabular}

a Abundance refers to relative abundance in dispersed-spore assemblages from the Rhynie boreholes.

drained southwards out of the Caledonian highlands, across the floodplain deposits of the Anglo-Welsh basin, before flowing into the Rheic ocean, represented by the shallow marine deposits of the Ardenne-Rhenish region (Bluck et al. 1992). Dispersed-spore assemblages coeval with those from Rhynie are known from both the AngloWelsh Basin (Hassan 1982; Richardson \& McGregor 1986; Wellman et al. 1998) and the Ardenne-Rhenish region (Steemans 1989). Comparisons indicate many similarities, in terms of the presence and relative abundance of taxa and morphotypes. However, there are some notable differences. Certain taxa and morphotypes, common in the floodplain and shallow-marine deposits, are rare or absent from Rhynie. Important missing taxa include Streelispora newportensis, Breconisporites breconensis and Clivosispora verrucata. Intriguingly, patinate spores, a very distinctive morphotype that is often diverse and abundant in Pragian spore assemblages, are represented at Rhynie only by rare laevigate forms, with ornamented forms being entirely absent. Similarly, spores belonging to the genus Dibolisporites are entirely absent. In the case of patinate spores, it seems likely that spores with this distinct morphotype represent a discrete group of plants, not present in the Rhynie assemblage. These findings suggest that certain plant species, and indeed groups, that were abundant on the lowland floodplains, and hence became incorporated in large numbers into the lowland-floodplain and nearshore-marine deposits, were virtually absent from the inland intermontaine regions. This palaeoecological variation is perhaps not surprising, and certainly not without precedent. In slightly earlier Lochkovian (Early Devonian) deposits, there are notable differences between spore assemblages, and indeed between plant megafossil assemblages, from the inland-intermontaine and floodplain deposits (Wellman et al. 2000). In fact, somewhat unexpectedly, these differences are more pronounced than in the Pragian. Such variation is almost certainly palaeoecological, probably relating to a variety of environmental factors such as water availability, nature of the substrate, climate and/or altitude.

\section{IN SITU SPORES}

The spores of Horneophyton lignieri are extremely distinctive and are unlikely to be confused with other spore taxa (figure $2 q-s$ ). They belong to the dispersed-spore taxon Emphanisporites decoratus, and spores included in this taxon almost certainly derive from a single plant taxon. This taxon is well known and has been widely reported in the palynological literature (figure $2 i-k, m, n$ ). It occurs in virtually all of the productive Rhynie samples, often in abundance (i.e. throughout the stratigraphical sequence-not just in the time interval when the hot springs were active). Furthermore, it is geographically widespread, occurring, often in relative abundance, in PE zone deposits of the Anglo-Welsh Basin (Hassan 1982; Wellman et al. 1998), Ardenne-Rhenish region (Steemans 1989), Spitzbergen (Allen 1965, 1967), Canada (McGregor \& Camfield 1976) and other localities. This strongly suggests that the parent plant, $H$. lignieri, was widespread and abundant. It might be argued that small, presumably wind-dispersed, spores such as those produced by $H$. lignieri have huge transportation potential and might have been transported by wind and water large 

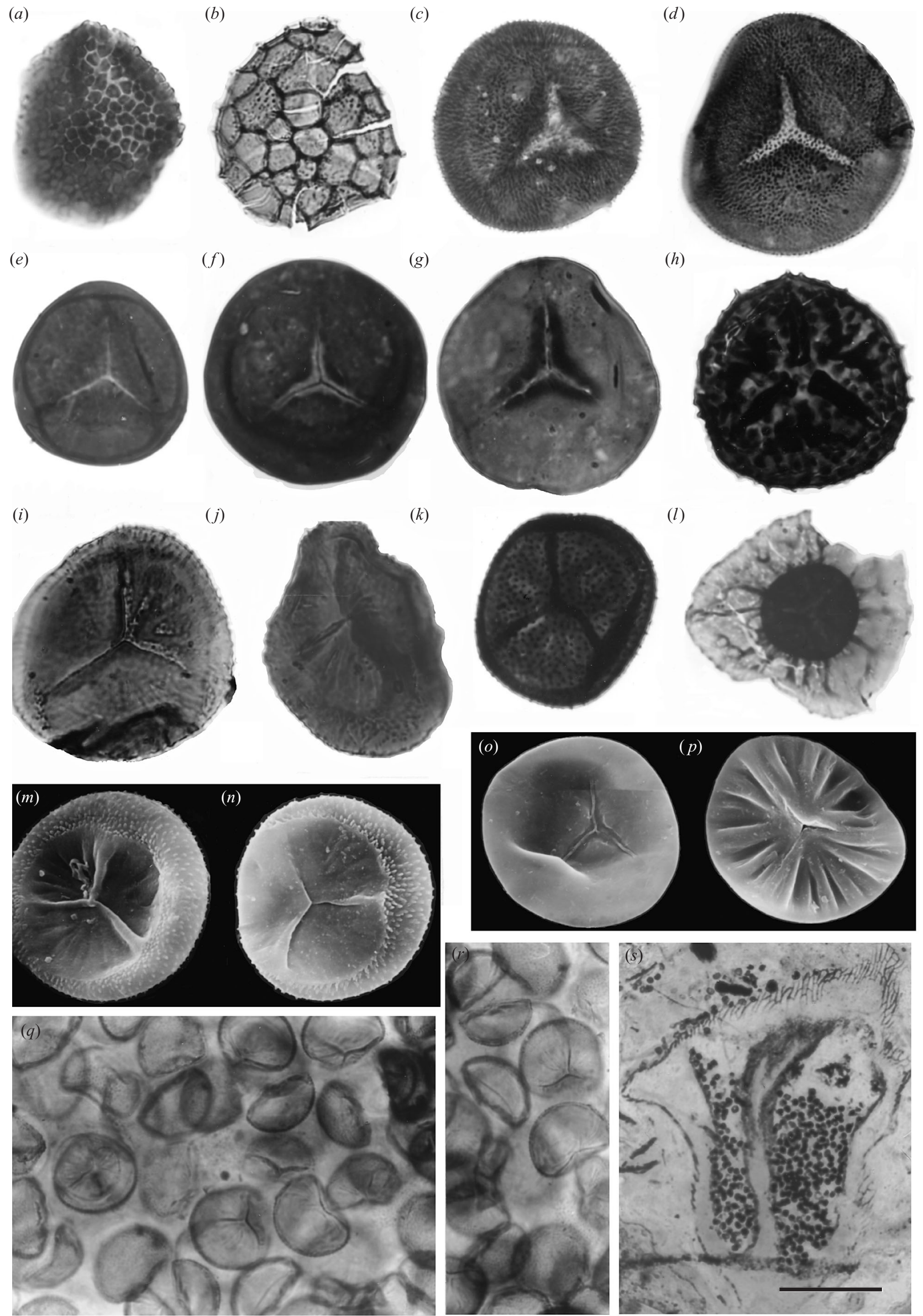

Figure 2. (Caption opposite.) 
Figure 2. $(a-l)$ Light microscope and $(m-p)$ scanning electron microscope images of dispersed spores and $(q-s)$ light microscope images of in situ spores. (a) Verrucosisporites polygonalis Lanninger; (b) Dictyotriletes subgranifer McGregor; (c) Apiculiretusispora plicata (Allen) Streel; (d) Apiculiretusispora plicata (Allen) Streel; (e) Retusotriletes sp.; $(f)$ Retusotriletes sp. A; $(g)$ Retusotriletes cf. triangulatus (Streel) Streel; (h) Emphanisporites zavallatus Richardson et al.; $(i-k)$ Emphanisporites decoratus Allen (note the intraspecific variation in the extent to which both ornament and proximal radial ribbing are developed); $(l)$ Camptozonotriletes caperatus McGregor; $(m, n)$ Emphanisporites decoratus Allen; (o) Retusotriletes sp. A; $(p)$ Emphanisporites rotatus (McGregor) McGregor; $(q, r)$ in situ $E$. decoratus from Horneophyton lignieri (note the well-developed proximal radial ribbing and the distal apiculate ornament); and (s) entire $H$. lignieri sporangium containing in situ spores (note the columella). Scale bar in $(s)$ applies to the whole figure, as follows: $20 \mu \mathrm{m}(a-d, g-k, m, n, p), 40 \mu \mathrm{m}(e, f, l, o), 60 \mu \mathrm{m}(q, r)$ and $100 \mu \mathrm{m}(s)$.

distances from where the plants were growing. While this huge transportation potential is accepted, it must be borne in mind that $E$. decoratus is often a relatively abundant spore, for example in Spitzbergen (Allen 1965, 1967) and the Anglo-Welsh Basin (Wellman et al. 1998), and it would not be expected to be widely dispersed in such large quantities. This provides compelling evidence that $H$. lignieri was a common plant of widespread distribution.

Horneophyton lignieri megafossils have not previously been reported outside the Rhynie cherts. This is almost certainly a consequence of the low fossilization potential of this plant. It has a largely parenchymatous construction, with little lignified tissue, and thus is unlikely to be preserved in normal conditions. Interestingly, a recently described plant from the Lochkovian of the Anglo-Welsh Basin has been placed in the genus Horneophyton based on morphological evidence (Edwards \& Richardson 2000). The in situ spores of this plant also consist of distally apiculate Emphanisporites (E. cf. micrornatus). This plant would not normally have been preserved but it was protected by an encrustation of some form of microbial or fungal growth. This specimen provides further evidence that Horneophyton was a common element of Lower Devonian floras, but is not preserved owing to taphonomic bias.

Similarly, Rhynia gwynne-vaughanii and Aglaophyton major have distinctive spore types (Apiculiretusispora plicata and Retusotriletes sp. A, respectively) that are readily recognized in dispersed-spore assemblages. They occur in abundance throughout the Rhynie sequence and are usually common in PE zone spore assemblages from the Old Red Sandstone continent. Again this suggests that these plants were thriving in the Rhynie drainage basin throughout its depositional history, and were palaeogeographically widespread.

The remaining four plants (Asteroxylon mackiei, Nothia aphylla, Trichopherophyton teuchansii and Ventarura lyonii) have spores with relatively simple morphology. Identical spores occur throughout the Rhynie sequence and are known globally from PE zone spore assemblages. However, because of their morphological simplicity, it is possible that similar spores were produced by a number of different plants through convergence. For example, a number of zosterophylls are known to have produced spores of the Retusotriletes $\mathrm{cf}$. triangulatus type. One must therefore be cautious in interpreting the distribution of these individual plant taxa based on spores, although it is clear that such spore types were produced by closely related plants.

\section{CONCLUSIONS}

Dispersed spores produced by the plants of the Rhynie cherts are abundant throughout the Rhynie sequence, providing evidence that at least three of the Rhynie plants were common elements of the Rhynie drainage basin and not confined to areas and times of hot-spring activity. Furthermore, these spores are palaeogeographically widespread and abundant elements of PE zone dispersed-spore assemblages, suggesting that the parent plants were common and widespread components of the regional flora. It is likely that the Rhynie plants thrived in the highly unusual and inhospitable hot-springs environment because they were preadapted to survive in such hostile conditions, not because they were highly adapted plants specialized for survival only in this peculiar environment. They also inhabited more normal environments throughout the remainder of the Rhynie drainage basin and in fact throughout a large area of the Old Red Sandstone continent. It is likely that they were the only elements of the regional flora that were capable of survival in the hotsprings environment (i.e. they were preadapted to survive around the hot springs, whereas other elements of the regional flora simply could not tolerate this inhospitable environment). This has major implications for palaeobotany. The interpretation of early land plants is over-reliant on information derived from the Rhynie plants. However, it has been a concern that the Rhynie plants were specialized and highly adapted, and hence not representative of early land plants. The studies reported herein suggest that this is not the case, and that the Rhynie plants probably provide a good model on which to base our interpretations of early land plants.

This research was supported by NERC grant GR9/03836. Nigel Trewin, Lyall Anderson and Steve Fayers provided access to the borehole material, and along with Dianne Edwards, Hagen Hass, Paul Kenrick and Hans Kerp allowed access to Rhynie chert material in their care. Extensive discussions provided by the Rhynie chert working group helped to formulate many of the ideas expressed herein.

\section{REFERENCES}

Allen, K. C. 1965 Lower and Middle Devonian spores of North and Central Vestspitsbergen. Palaeontology 8, 687748.

Allen, K. C. 1967 Spore assemblages and their stratigraphical implications in the Lower and Middle Devonian of North and Central Vestspitsbergen. Palaeontology 10, 280-297.

Allen, K. C. 1980 A review of in situ Late Silurian and Devonian spores. Rev. Palaeobot. Palynol. 29, 253-270.

Bhutta, A. A. $1973 a$ On spores (including germinating spores) of Rhynia major Kidston \& Lang. Biologia 19, 47-57.

Bhutta, A. A. $1973 b$ On the spores (including germinating spores) of Horneophyton (Hornea) lignieri (Kidston \& Lang) Barghoorn \& Darrah (1938). Pak. F. Bot. 5, 45-55. 
Bluck, B. J., Cope, J. W. C. \& Scrutton, C. T. 1992 Devonian. In Atlas of palaeogeography and lithofacies (ed. J. C. W. Cope, J. K. Ingham \& P. F. Rawson), pp. 57-66. London: The Geological Publishing House.

Croft, W. N. \& George, E. A. 1959 Blue-green algae from the Middle Devonian of Rhynie, Aberdeenshire. Bull. Br. Mus. (Nat. Hist.) Geol. 3, 341-353.

Darrah, W. C. 1960 Principles of paleobotany. New York: The Ronald Press Company.

Edwards, D. \& Richardson, J. B. 1996 Review of in situ spores in early land plants. In Palynology: principles and applications (ed. J. Jansonius \& D. C. McGregor), pp. 391-408. Salt Lake City, UT, USA: American Association of Stratigraphic Palynologists Foundation.

Edwards, D. \& Richardson, J. B. 2000 Progress in reconstructing vegetation on the Old Red Sandstone continent: two Emphanisporites producers from the Lochkovian sequence of the Welsh Borderland. In New perspectives on the Old Red Sandstone (ed. P. F. Friend \& B. P. J. Williams), pp. 355-370. Special publication 180. London: Geological Society.

Edwards, D. S. \& Lyon, A. G. 1983 Algae from the Rhynie Chert. Bot. F. Linn. Soc. 86, 37-55.

Gensel, P. G. 1980 Devonian in situ spores: a survey and discussion. Rev. Palaeobot. Palynol. 30, 101-132.

Hassan, A. 1982 Palynology, stratigraphy and provenance of the Lower Old Red Sandstone of the Brecon Beacons (Powys) and Black Mountains (Gwent and Powys), South Wales. Unpublished PhD thesis, University of London, Kings College.

Kidston, R. \& Lang, W. H. 1917 On Old Red Sandstone plants showing structure, from the Rhynie chert bed, Aberdeenshire. Trans. R. Soc. Edinb. 51, 761-784.

Kidston, R. \& Lang, W. H. $1920 a$ On Old Red Sandstone plants showing structure, from the Rhynie chert bed, Aberdeenshire. Part II. Additional notes on Rhynia gwynnevaughani, Kidston and Lang: with descriptions of Rhynia major, N. sp., and Hornea lignieri, N. G. N. sp. Trans. R. Soc. Edinb. 52, 603-627.

Kidston, R. \& Lang, W. H. $1920 b$ On Old Red Sandstone plants showing structure, from the Rhynie chert bed, Aberdeenshire. Part III. Asteroxylon mackiei Kidston and Lang. Trans. R. Soc. Edinb. 52, 643-680.

Kidston, R. \& Lang, W. H. 1921a On Old Red Sandstone plants showing structure, from the Rhynie chert bed, Aberdeenshire. Part IV. Restorations of the vascular cryptogams, and discussion of their bearing on the general morphology of the Pteridophyta and the origin of the organisation of land plants. Trans. R. Soc. Edinb. 52, 831-854.

Kidston, R. \& Lang, W. H. $1921 b$ On Old Red Sandstone plants showing structure, from the Rhynie chert bed, Aberdeenshire. Part V. The thallophyta occurring in the peat bed, and the conditions of accumulation and preservation of the deposit. Trans. R. Soc. Edinb. 52, 855-902.

Lyon, A. G. 1957 Germinating spores in the Rhynie chert. Nature 180, 1219-1221.

McGregor, D. C. \& Camfield, M. 1976 Upper Silurian? To Middle Devonian spores of the Moose River Basin, Ontario. Geol. Surv. Can. Bull. 263, 1-63.

Powell, C. L., Trewin, N. H. \& Edwards, D. 2000 Palaeoecology and plant succession in a borehole through the Rhynie cherts, Lower Old Red Sandstone, Scotland. In New perspectives on the Old Red Sandstone (ed. P. F. Friend \& B. P. J. Williams), pp. 439-457. Special publication 180. London: Geological Society.

Remy, W. \& Hass, H. 1996 New information on gametophytes and sporophytes of Aglaophyton major and inferences about possible environmental adaptations. Rev. Palaeobot. Palynol. 90, 175-193.

Remy, W. \& Remy, W. 1980 Devonian gametophytes with anatomically preserved gametangia. Science 208, 295-296.

Remy, W., Gensel, P. G. \& Hass, H. 1993 The gametophyte generation of some Early Devonian land plants. Int. F. Pl. Sci. 154, 35-58.

Rice, C. M. (and 13 others) 1995 A Devonian auriferous hot spring system, Rhynie, Scotland. f. Geol. Soc. Lond. 152, 229-250.

Rice, C. M., Trewin, N. H. \& Anderson, L. I. 2002 Geological setting of the Early Devonian Rhynie cherts, Aberdeenshire, Scotland: an early terrestrial hot spring system. F. Geol. Soc. Lond. 159, 203-214.

Richardson, J. B. \& McGregor, D. C. 1986 Silurian and Devonian spore zones of the Old Red Sandstone continent and adjacent areas. Geol. Surv. Can. Bull. 364, 1-79.

Scott, D. H. 1920 Studies in fossil botany, 3rd edn. London: A. \& C. Black Ltd.

Steemans, P. 1989 Etude palynostratigraphique du Devonien Inferieur dans l'ouest de l'Europe. Mémoires pour servir à l'Explication des Cartes Geologiques et Minières de la Belgique. Memoir no. 27.

Streel, M., Loboziak, S., Steemans, P. \& Bultynck, P. 2000 Devonian miospore stratigraphy and correlation with the global stratotype sections and points. Courier Forschungsinstitut Senckenberg 220, 9-23.

Taylor, T. N. \& Taylor, E. L. 2000 The Rhynie chert ecosystem: a model for understanding fungal interactions. In Microbial endophytes (ed. C. W. Bacon \& J. F. White), pp. 31-47. New York: Mercel Dekker.

Taylor, T. N., Hass, H. \& Kerp, H. 1997 A cyanolichen from the Lower Devonian Rhynie chert. Am. F. Bot. 84, 9921004.

Trewin, N. H. 1994 Depositional environment and preservation of biota in the Lower Devonian hot-springs of Rhynie, Aberdeenshire, Scotland. Trans. R. Soc. Edin. Earth Sci. 84, 433-442.

Trewin, N. H. 1996 The Rhynie cherts: an early Devonian ecosystem preserved by hydrothermal activity. In Evolution of hydrothermal ecosystems on Earth (and Mars?) (ed. G. R. Bock \& J. Goode), pp. 131-149. Chichester: Wiley.

Trewin, N. H. \& Rice, C. M. 1992 Stratigraphy and sedimentology of the Devonian Rhynie chert locality. Scot. F. Geol. 28, 37-47.

Wellman, C. H., Thomas, R. G., Edwards, D. \& Kenrick, P. 1998 The Cosheston Group (Lower Old Red Sandstone) in southwest Wales: age, correlation and palaeobotanical significance. Geol. Mag. 135, 397-412.

Wellman, C. H., Habgood, K., Jenkins, G. \& Richardson, J. B. 2000 A new plant assemblage (microfossil and megafossil) from the Lower Old Red Sandstone of the Anglo-Welsh Basin: its implications for the palaeoecology of early terrestrial ecosystems. Rev. Palaeobot. Palynol. 109, 161-196.

As this paper exceeds the maximum length normally permitted, the author has agreed to contribute to production costs. 